\title{
IMMIGRANT LABOUR IN BRAZIL (2007-2015): THE LEGAL AND THE UNDOCUMENTED CIRCUITS
}

\author{
P. Villen \\ University of Campinas (Unicamp - Brazil) \\ Barão Geraldo, Campinas - SP, Brazil, 13083-970
}

\begin{abstract}
This paper analyzes labor immigration to Brazil in a historical and modern aspect. The historical features of immigration processes are established, as well as the evolution of the state immigration policy in Brazil. It is established that the era of slavery played an important role in the formation of the Brazilian labor market. The importation of slaves from Africa continued even after independence was declared in 1822. The transition from slave labor to the wage labor occurred in the second half of the twentieth century. Subsequently, Brazil's immigration policy was based on a quota system to protect the domestic labor market and reduce unemployment among the local population. At the present stage, the policy of protecting the domestic labor market of Brazil is still conducted, on the basis of a selective approach. As a basic mechanism of regulation are working visas. It is revealed that as globalization processes develop, Brazil faces new challenges, including mass flows of undocumented immigrants from the less developed countries of Latin America. The impact of the global economic crisis on migration in Brazil has been revealed.
\end{abstract}

Key words: immigrant labour, Brazil, undocumented circuits

\section{Introduction}

Brazil has an old immigration history connected to the labour market dynamics. It begins in the Modern Ages with the massive importation of slave labour in Africa during the colonial period. The slave labour inflows have continued even after the country's independence (1822), particularly until 1850 (slavery trafficking abolition). This history included the international supply system of "coolies" during the second half of the XIX" century (Potts L., 1990). The period of transition from slavery to wage labour (second half of the nineteenth century until the early twentieth) illustrated what Castles \& Miller (1993) have called the "age of migration". Mostly Europeans and Japanese — but also other nationalities - immigrated either "spontaneously" or due to public and private funding in order to supply the wage labour market, in particular for the agricultural and the incipient industrial sectors.

The 1930s symbolizes the first borders "closure" to immigration in Brazil. This policy was justified to deal with the so-called causes of "unemployment", "increased economic disorder" and "social insecurity" (Law n. 19.498 /1930; Carneiro M.T.C. et al., 2010). Differently from what had characterized the history of immigration until this moment, for the first time the massive inflows of white free workers were restricted by a quota's system. 
In later decades, despite the significant drop of the foreign population - from $5.11 \%$ in 1920 Census to $0.77 \%$ in the 1980 's one (Bassanezi, 1995) - the same concern about national workers' "protection" was kept. In the 1980's the supposed neutral selective regime based on qualification-specialization was inaugurated with the Law n. 68.815/1980, the Estatuto do Imigrante, which is still valid (2016). Since then, the immigrant who is formally allowed to work in Brazil is the one who demonstrates not "threatening" the national worker, i.e. who proves to have a professional qualification or specialization that is required in Brazil.

This policy resulted in restricted inflows within the legalized immigration circuit (work visa), which are selected to some strategic sectors - often linked to foreign capital investments or to a shortage of professionals. In parallel, there are much wider population movements from peripheral countries, usually persons in vulnerable socioeconomic situation and undocumented. This trend is not new in Brazil, it dates at least from the $1960^{\text {th }}$ (Villen P., 2015). Nevertheless, this article will show how it takes force after the beginning of the global crisis (2007) in Brazilian context.

Saskia Sassen's studies contribute for the understanding of this polarized configuration through a wider theoretical framework about the new international migration circuits in a global scale. Sassen (2014) reveals that these circuits are dynamic, multi-sited and strongly influenced by the transnational space of capital circulation and the policies that enable this system. According to this author, the international circulation of migrant workers reveals a trend for a polarized configuration that can be clearly seen in the socalled "global cities". In one hand, her researches indicate the high skilled workers flows directed to "strategic economic sectors" (Sassen 2011: 142). In the other hand, it shows the demand for workers from peripheral countries, particularly women who usually earn low wages in the black market and live in an undocumented situation.

The economy of services in the global cities explains the demand for workers with a high qualified technical knowledge and/or specialized in some particular sectors, i.e. the "leader economic sectors" (mainly TICs and financial services). This demand is supported by immigration policies through a bureaucratic selective process. However, this pole coexists with much larger international migrant flows that are obliged to face restrictive policies and are "never represented as part of the global economy" (Sassen, 2011). Despite that, these flows are linked to a demand for flexible, manual, low wage and low qualified jobs (Basso, 2010; Schierup, 2007; Dreher, 2007). The gender perspective is very necessary to investigate this pole of immigrant labour, because of its high share of women working in precarious jobs (Morokvasic, 2011; Lutz, 2007, Enrenreich \& Hochschild, 2003).

This theoretical framework is very useful to discuss the new social basis of immigration in Brazil and its largest representation from peripheral countries (Latin America, Africa and Asia) - that are usually invisible in official statics. The purpose of this article is to analyse the literature about international inflows to Brazil during the period 2007-2015, also considering the statistics by the Ministry of Labour and Employment concerning the visa regime and the gender and nationality shares. The interest for this period comes from the high economic growth and the dynamics of labour market in Brazil - which had interesting consequences over the immigration flows. The next two sections will present the general features of the manifestation of the two poles inflows in Brazil: i) The pole of the immigration for skilled and specialized labour; ii) The pole of the emergency peripherals. Some final remarks conclude the paper. 


\section{The pole of the immigration for skilled and specialized labour}

The pole of the immigration for skilled and specialized labour is a very selective and bureaucratic circuit of legal immigration that has become more important in the last decade. The data concerning the work visas publicized by the Brazilian Ministry of Labour and Employment allows us to understand the main trends in this pole.

In Brazil this circuit is the only that can have visa work. It includes different professional categories as well as demanding sectors, several countries of origin and a low composition of women (except in the case of the physicians). These inflows are usually linked to transnational companies and to foreign capital investments. Nevertheless, some categories such as physicians, professors, researchers and the so called "global sea workers" (Zanin, 2007) have had an unprecedented increase in the last years. This pole has a high level of formal education and working age profile, generally with University degrees.

Table 1 leaves no doubt about the significant increase in the working visas from 2007 to 2008 , when it rose from 29,488 to nearly 44,000 , keeping its growing path in the following period, when it surpassed the 60,000 annual visas. After 2014, however, Brazil is under an economic crisis that is causing increasing unemployment rates and decreasing foreign direct investment in the country. Thus, the skilled and specialized immigration inflows also declined, as Table 1 shows.

Table 1

Work visas, Brazil (1993 to 2015)

\begin{tabular}{|c|c|c|c|c|c|}
\hline Year & $\begin{array}{l}\mathrm{N} .{ }^{\circ} \text { of migrant } \\
\text { workers }\end{array}$ & Year & $\begin{array}{l}\mathrm{N} .{ }^{\circ} \text { of migrant } \\
\text { workers }\end{array}$ & Year & $\begin{array}{l}\mathrm{N} .{ }^{\circ} \text { of migrant } \\
\text { workers }\end{array}$ \\
\hline 1993 & 5,376 & 2001 & 15,903 & 2009 & 42,914 \\
\hline 1994 & 4,236 & 2002 & 18,062 & 2010 & 55,471 \\
\hline 1995 & 3,792 & 2003 & 17,389 & 2011 & 69,077 \\
\hline 1996 & 4,002 & 2004 & 20,315 & 2012 & 67,220 \\
\hline 1997 & 7,090 & 2005 & 24,158 & 2013 & 62,387 \\
\hline 1998 & 14,110 & 2006 & 25,440 & 2014 & 46,740 \\
\hline 1999 & 12,709 & 2007 & 29,488 & 2015 & 36,868 \\
\hline 2000 & 14,741 & 2008 & 43,993 & & \\
\hline
\end{tabular}

Source: Ministério do Trabalho e Emprego (Base Estatística - CNIg).

The international mobility of skilled/specialized professionals has a clear "gender bias" presented and discussed by many contemporary studies in several countries (e.g. Campani, 2011; Roulleau-Berger, 2010; Preston and D’Addario, 2009). According to Table 2, the percentage of work visas for women in Brazil has been fluctuating in a level slightly above $10 \%$.

Table 2

Work visas by gender (2006-2015)

\begin{tabular}{|l|l|l|l||l|l|l|l|}
\hline \multicolumn{1}{|c|}{ Year } & \multicolumn{1}{|c|}{ Male } & \multicolumn{1}{|c|}{ Female } & \multicolumn{1}{|c|}{ Total } & \multicolumn{1}{|c|}{ Year } & \multicolumn{1}{c|}{ Male } & \multicolumn{1}{c|}{ Female } & \multicolumn{1}{c|}{ Total } \\
\hline 2006 & 23,608 & 1,832 & 25,440 & 2011 & 62,807 & 6,990 & 69,077 \\
\hline 2007 & 26,471 & 3,017 & 29,488 & 2012 & 60,807 & 6,413 & 67,220 \\
\hline 2008 & 39,551 & 4,442 & 43,993 & 2013 & 55,728 & 6,659 & 62,387 \\
\hline 2009 & 39,119 & 3,795 & 42,914 & 2014 & 41,602 & 5,138 & 46,740 \\
\hline 2010 & 35,493 & 3,564 & 39,057 & 2015 & 32,479 & 4,389 & 36,868 \\
\hline
\end{tabular}

Source: Ministério do Trabalho e Emprego (Base Estatística - CNIg). 
Table 3 indicates the Brazilian state policy concerning the working visa length: a temporary regime (which includes visas for 90 days, one year or two years) clearly predominates. It illustrates the "circulation" policy, a tendency that has been studied in many other countries regarding the usage of temporary regimes to manage the immigration flows - even the high skilled one (Martin et. al. 2006). Pizarro (2005) arguments that the global market of qualified human resources, regulated by the General Agreement on Trade in Services (Gats), do not include citizenship and residence rights. The Brazilian Ministry of Labour and Employment's data reveals that the 90 days work visas (the shortest one) correspond to 30 to $45 \%$ of the temporary visas shedding light over the volatility of the migration inflows and outflows.

Table 3

Work visas by length (2006-2015)

\begin{tabular}{|l|l|l|l||l|l|l|l|}
\hline & $\begin{array}{c}\text { Permnent visa } \\
(5 \text { years })\end{array}$ & Temporay visa & Total & & $\begin{array}{c}\text { Permnent visa } \\
(5 \text { years })\end{array}$ & Temporay visa & Total \\
\hline 2006 & 2,055 & 23,385 & 25,440 & 2011 & 2,686 & 66,391 & 69,077 \\
\hline 2007 & 2,615 & 26,873 & 29,488 & 2012 & 2,938 & 64,282 & 67,220 \\
\hline 2008 & 2,722 & 41,271 & 43,993 & 2013 & 2,959 & 59,428 & 62,387 \\
\hline 2009 & 2,454 & 40,460 & 42,914 & 2014 & 2,843 & 43,897 & 46,740 \\
\hline 2010 & 2,247 & 53,224 & 55,471 & 2015 & 2,332 & 34,536 & 36,868 \\
\hline
\end{tabular}

Source: Ministério do Trabalho e Emprego (Base Estatística - CNIg).

Table 4 highlights the nationality participation of work visas. The leading position is from central countries or from those with an "intermediate position" in the world market (India, China, South Korea). The Philippines and Indonesia represent exceptions that will be analysed below.

Table 4

Work visas by country of origin (2006-2014)

\begin{tabular}{|l|l|l|l|l|l|l|l|l|l|l|}
\hline Country of origin & \multicolumn{1}{|c|}{2006} & 2007 & \multicolumn{1}{|c|}{2008} & 2009 & 2010 & 2011 & 2012 & 2013 & 2014 & 2015 \\
\hline USA & 3,601 & 4,519 & 5,799 & 5,590 & 7,520 & 10,098 & 9,138 & 8,943 & 5,830 & 5,519 \\
\hline Philippines & 1,542 & 2,120 & 4,825 & 4,969 & 6,530 & 7,798 & 5,179 & 5,117 & 4,486 & 2,994 \\
\hline United Kingdom & 2,199 & 2,474 & 3,874 & 3,496 & 3,828 & 2,500 & 4,363 & 4,089 & 3,296 & 2,610 \\
\hline India & 766 & 1,292 & 1,981 & 2,630 & 3,234 & 4,262 & 4,235 & 3,756 & 2,663 & 2,251 \\
\hline Italy & 1,099 & 1,382 & 1,413 & 1,395 & 2,006 & 2,421 & 2,999 & 2,688 & 2,545 & 1,954 \\
\hline Spain & 655 & 878 & 1,133 & 1,104 & 1,425 & 1,844 & 1,992 & 2,677 & 2,229 & 1,210 \\
\hline Portugal & 477 & 550 & 679 & 708 & 757 & 1,547 & 2,171 & 2,913 & 1,921 & 1,294 \\
\hline France & 1,210 & 1,377 & 1,613 & 1,908 & 1,597 & 2,166 & 2,369 & 2,265 & 1,785 & 1,475 \\
\hline China & 717 & 1,078 & 2,422 & 1,405 & 2,154 & 2,639 & 3,082 & 2,354 & 1,561 & 1,405 \\
\hline Germany & 1,553 & 1,292 & 1,815 & 1,454 & 2,873 & 3,162 & 3,589 & 2,900 & 1,437 & 1,255 \\
\hline South Korea & 253 & 126 & 203 & 214 & 897 & 1,440 & 2,311 & 1,461 & 1,429 & 1,936 \\
\hline Japan & 1,278 & 1,244 & 1,804 & 1,237 & 1,761 & 2,260 & 2,316 & 2,024 & 1,352 & 1,296 \\
\hline Indonesia & 126 & 267 & 1,356 & 1,700 & 1,819 & 2,682 & 2,306 & 2,253 & 1,130 & 325 \\
\hline Russia & 435 & 495 & 680 & 539 & 578 & 919 & 842 & 863 & 765 & 854 \\
\hline Others & 9,420 & 10,268 & 14,150 & 14,324 & 18,492 & 23,339 & 20,328 & 18,084 & 14,311 & 10,490 \\
\hline Total & 25,331 & 29,362 & 43,747 & 42,673 & 55,471 & 69,077 & 67,220 & 62,387 & 46,740 & 36,868 \\
\hline
\end{tabular}

Source: Ministério do Trabalho e Emprego (Base Estatística - CNIg). 
The oil industry is the most important branch of migrant labour attraction. This industry has expanded over the past two decades in Brazil, achieving a particular attention at the global market after the discovery of the Pré Sal reserves. Although there are no studies about this subject, the increase of the so called "global sea workers" inflows in Brazil had already been noticed by a leading expert on this topic, the Italian sociologist Valter Zanin (2007). His study pointed out that Brazil in the last decade was emerging as a significant employer of this category. Table 5 shows the high labour migrant inflows directed to this sector.

Table 5

Temporary work visas (foreign ship or platform allowed to operate in Brazil)

\begin{tabular}{|l|l||l|l|}
\hline \multicolumn{1}{|c|}{ Year } & \multicolumn{1}{|c|}{ N. work visas } & \multicolumn{1}{|c|}{ Year } & \multicolumn{1}{c|}{ N. work visas } \\
\hline 2006 & 7,405 & 2011 & 17,738 \\
\hline 2007 & 7,756 & 2012 & 15,554 \\
\hline 2008 & 10,974 & 2013 & 15,229 \\
\hline 2009 & 13,371 & 2014 & 14,931 \\
\hline 2010 & 15,207 & 2015 & 10,625 \\
\hline
\end{tabular}

Source: Ministério do Trabalho e Emprego (Base Estatística - CNIg).

Table 6 shows that the Philippines is by far the main supplier country of this migrant labour.

Table 6

Temporary work visa (foreign ship or platform allowed to operate in Brazil) by nationalities

\begin{tabular}{|l|l|l|l|l|l|}
\hline \multicolumn{1}{|c|}{ Nationality } & \multicolumn{1}{c|}{2011} & \multicolumn{1}{c|}{2012} & \multicolumn{1}{c|}{2013} & \multicolumn{1}{c|}{2014} & \multicolumn{1}{c|}{2015} \\
\hline Philippines & 3,583 & 3,615 & 3,584 & 3,475 & 2,759 \\
\hline United Kingdom & 1,814 & 1,486 & 1,692 & 1,530 & 1,034 \\
\hline India & 1,432 & 1,278 & 1,110 & 981 & 1,075 \\
\hline USA & 1,777 & 1,090 & 927 & 766 & 297 \\
\hline Poland & 741 & 616 & 705 & 680 & 505 \\
\hline Ukraine & 434 & 555 & 599 & 588 & 490 \\
\hline Norway & 1,076 & 519 & 658 & 558 & 313 \\
\hline Greece & 345 & 486 & 546 & 427 & 479 \\
\hline Russia & 527 & 508 & 460 & 248 & 311 \\
\hline France & 404 & 401 & 348 & 211 & 198 \\
\hline Others & 5,605 & 5,401 & 4,600 & 5,467 & 3,164 \\
\hline Total & 17,738 & 15,955 & 15,229 & 14,931 & 10,625 \\
\hline
\end{tabular}

Source: Ministério do Trabalho e Emprego (Base Estatística - CNIg).

In the last four years, the migrant labour inflows directed to public health services and higher education system have had a significant grow. It denotes the participation of the Brazilian State as a direct consumer of the migrant labour. This fact is not completely new - considering the last two decades - but it used to be much more limited in numbers. There are significant changes after the implementation of the Mais Médicos Program as well as the increasing recruitment of Professors and researchers by public Universities (State and Federal ones).

Concerning Mais Médico Program, from 2013 to 2014, 12,165 foreign physicians were recruited to work in 2,177 municipalities of Brazil. The contract is temporary (three years 
renewable once, for the same period). The mainly nationality participation was of Cubans, 11,452 (6,676 women and 4,776 men), followed by Venezuelans (151), Argentinians (145), Uruguayans (66) and Bolivians (72). Spanish (54) and Portuguese (24) are the main representative nationalities from central countries. As a whole, the program involves professionals from 49 different nationalities. In a countertrend of the typical gender imbalance of this pole, women physicians exceed men - respectively 6,974 and 5,191.

The Brazilian public University is also an important insertion sector for immigrants with high qualification profile. Before the crises manifestation in Brazil (2014), there were several public policies (scholarships and exchange programs) being implemented, particularly for the hard sciences and technologies areas. Data from the Ministery of Education show that the number of foreign Professors in Brazilian Universities is slightly above 4,000. In 2013, the mainly representative countries of origin are Argentine (12,9\%), Peru (12,8\%), Portugal (7,9\%), Italy (5,9\%), Chile $(5,85 \%)$.

\section{The pole of the emergency peripherals}

This section will analyse the social basis of immigration that is not fully visible in the official statistics, despite it constitutes the most important trend of the inflows to Brazil in the last four decades. It refers to immigrants and asylum seekers from peripheral countries that usually arrive through border flows, intraregional flows (Mercosul) and the undocumented circuit. In Brazil, the inflows from peripheral countries started increasing mainly in the end of the 1960s, in particular with the Korean and Bolivian inflows to S o Paulo city directed to textile activities (Silva, 2008). In the twenty-first century, these inflows start to include different nationalities of immigrants and asylum seekers, mainly from Latin America, Africa and Asia (Baeninger, 2013).

The national policy to manage those inflows does not offer work visas. Actually, these inflows are officially presented as an emergency case in the Brazilian immigration history. It means there is not a perennial (or a structured) policy to deal with this inflows, but only emergency policies. For these reason, there are usually no official and trustworthy data concerning these flows.

Many studies have pointed out how precarious is the working condition in the pull sectors which the emergency peripherals are directed, such as textile industry, meat slaughtering, construction, domestic work among others (Mamed, 2014; Silva, 2008). Although the existence of a high demand from these sectors, it do not formally represent a legal circuit for work visas. Concerning immigrant women, until now the textile industry is the most important pull sector, even if these women work in a variety categories of jobs, also the care and domestic work.

In fact, the "peripherals at the periphery" (Villen, 2015) denote a specific way to migrate from a peripheral country to another peripheral one that includes immigrants and asylum seekers. It means to migrate having almost no money (what engenders in many cases the situation of indebtedness) and using the undocumented circuit, sometimes passing by different countries before. Their economic vulnerability situation explains why they need to seek immediately an employment to survive and to help their family in the country of origin. Arriving in Brazil, these migrants continue to face difficult conditions of living and working, because of the low wages and precarious standard of labour in Brazil (Antunes, 2014). It reflects an exposure to exploration at work and in all spheres 
of social life where their presence can be profitable for others - i.e. the entrepreneurs borders, the agencies that charge extremely high fees to send remittances, the landlords that require very high prices to rent residences or rooms to immigrants dividing only a few square meters (often unhealthy).

Moreover, these bad conditions of working and living in Brazil for peripheral immigrants and asylum seekers reflect a socio-economic and cultural marginality, produced and reproduced by several mechanisms, mainly by racism above all structured by and at work (Sayad, 1999; Basso, 2010; Perocco, 2011). For many of them, the asylum request and the humanitarian visa (special category of visa created to Haitians) are the only way to get a provisory regularization.

The data concerning the stock of peripheral nationalities are mixed with the old immigration in Brazil that is mainly composed by European countries. Table 7 reflects the clearly underestimated stock of foreigners from peripheral countries - Demographic Census (2010) - in São Paulo state that is the main inflows direction during the last decades.

Table 7

Stock of foreigners in the state of São Paulo, Census IBGE (2010)

\begin{tabular}{|l|l||l|l||l|l|}
\hline \multicolumn{1}{|c|}{ Nationality } & \multicolumn{1}{c|}{2010} & \multicolumn{1}{c|}{ Nationality } & \multicolumn{1}{c|}{2010} & \multicolumn{1}{c|}{ Nationality } & \multicolumn{1}{c|}{2010} \\
\cline { 2 - 2 } Portuguese & 53,414 & South Korean & 6,457 & French & 2,437 \\
\hline Japonesese & 23,904 & German & 4,494 & English & 2,198 \\
\hline Bolivian & 22,658 & African & 4,349 & Colombians & 1,518 \\
\hline Italian & 15,388 & Paraguayan & 4,226 & British & 1,025 \\
\hline Spanish & 13,990 & Peruvian & 4,080 & Mexican & 1,015 \\
\hline Chinese & 9,372 & Libanese & 3,397 & Venezuelan & 834 \\
\hline Chilean & 7,438 & American & 3,567 & Equatorian & 519 \\
\hline Argentin & 6,929 & Uruguayn & 2,480 & Austrían & 122 \\
\hline
\end{tabular}

Source: Own elaboration based on the data of Thematic Atlas of the Migration Observatory in São Paulo (Baeninger, 2013).

Concerning the stock of foreigners in the whole country, the last Census (2010) reveals that $68.3 \%$ of this population were in working age, $60 \%$ were men and $42.5 \%$ had no (or less than for years of) formal education, $22.7 \%$ had high school degree and $23.1 \%$ had higher education degree.

The list of "extraordinary" regularized immigrants in Table 8 reveals the diversity of nationalities that did not receive the refugee status, but were settled into an "emergency" policy between 2011 and 2013 .

In order to highlight the main trends of this pole of immigration, this article suggests a division into three groups, concerning the country of origin or the undocumented way to arrive in Brazil.

The first group refers to inflows from Mercosul (Argentina, Uruguay and Paraguay) and associated countries (Bolivia, Colombia, Chile and Venezuela). These intraregional inflows (especially from countries that have boarders with Brazil) are continuously in the Brazilian immigration scenario, particularly after the late 1960s. Actually, those inflows anticipate by far the Asunción Agreement (1991) establishing the Southern Common Market (Mercosul) and it's residence Agreement (2009) for Mercosul citizens. Before 
this agreement, those inflows were largely undocumented. However, the immigrants from those countries still have to face a very bureaucratic system. Actually, they are not protected of the undocumented situation. These inflows are predominantly directed to São Paulo city (Baenniger, 2013).

Table 8

Extraordinary regularization by nationality in Brazil (2011-2013)

\begin{tabular}{|l|l||l|l||l|l|}
\hline $\begin{array}{c}\text { Country } \\
\text { of origine }\end{array}$ & $\begin{array}{c}\text { N. immigrant/ } \\
\text { asylum seekers }\end{array}$ & $\begin{array}{c}\text { Country } \\
\text { of origine }\end{array}$ & $\begin{array}{c}\text { N. immigrant/ } \\
\text { asylum seekers }\end{array}$ & $\begin{array}{c}\text { Country } \\
\text { of origine }\end{array}$ & $\begin{array}{c}\text { N. immigrant/ } \\
\text { asylum seekers }\end{array}$ \\
\cline { 2 - 5 } Bangladesh & 2,040 & Angola & 78 & Ecuador & 21 \\
\hline Senegal & 989 & R. D. Congo & 63 & Egyte & 16 \\
\hline Guinea-Bissau & 221 & Nigéria & 52 & Gambia & 15 \\
\hline Ghana & 194 & Colombia & 48 & Guinea-Conacri & 15 \\
\hline Pakistan & 146 & Nepal & 40 & China & 11 \\
\hline Somalia & 141 & India & 39 & Others & 69 \\
\hline Rep. Dominicana & 133 & Serra Leoa & 26 & Total & 4,481 \\
\hline Cuba & 100 & Burkina Faso & 24 & & \\
\hline
\end{tabular}

Source: Conselho Nacional de Imigração (2014).

The second group refers to the massive inflows of Haitians that are new in Brazilian immigration history. It began to emerge in 2011, after the earthquake that devastated that island in 2010. According to the data provided by Dutra et al. (2014: 51), based on the analysis of the RAIS (Brazilian formal labour market data), between 2011 and 2013 the presence of Haitians in formal labour market increased from 814 people (726 men and 88 women) in 2011 to 4,117 (3,606 men and 511 women) in 2012, reaching 14,579 workers in 2013 (12,518 men and 2,061 women).

Thus, in just four years, these inflows which began in hundreds of people multiplied into thousands. It is a real exodus that takes away from Haiti mainly men in working age, but also women, teenagers, children and elder people, according to the notes about sociological profile of Haitian immigrants arriving in undocumented situation in Acre, Northern state in Brazil (Mamed, 2014). The unofficial data estimates the presence of 50,000 Haitians in Brazil in 2014. The humanitarian visa is a special and emergency regime that Brazilian state has used to regularize these inflows. In addition to the annual quota of 1,200 humanitarian visas granted in the Brazilian Embassy in Haiti, these inflows have taken the dimension of an undocumented mass.

Several media reports have documented the emergency way in which most of these inflows arrive in Brazil, usually crossing borders in the North of the countries (Amazonic Forest), after having made a long and risky trip intermediated by network agencies, often passing through different countries (Dominican Republic, Panama, Colombia, Ecuador, Peru, Bolivia) and paying high prices to the "coyotes".

The third group consists of asylum-seekers. According to CONARE (National Committee for refugees), in 2016 there were the stocks of eight thousand refugees in Brazil from 79 different nationalities. The leading nationalities position are Syrian $(2,298)$, Angolan (1,420), Colombian (1,100) and Congolese (968), Palestinian (376). Among refugee stocks, $71,8 \%$ are male mostly $(78,8 \%)$ of $18-59$ age (Conare, 2016). Concerning 
the asylum request stocks, the top nationalities are from Haiti $(48,371)$, Senegal $(7,206)$, Syria $(3,460)$, Bangladesh $(3,287)$, Angola $(2,281)$, Congo $(2,167)$, Gana $(2,166)$, Libano $(1,749)$ and Venezuela $(1,525)$. Among the asylum request stocks, $80,8 \%$ are male mostly (95\%) of 18-59 age (Conare, 2016). The Figure points out an increase of asylum seekers inflows. It also highlights that the number of applications (which are still not analysed) is higher than the accepted ones, i.e. those asylum seekers can easily became undocumented.

Applications
(flow in each year)

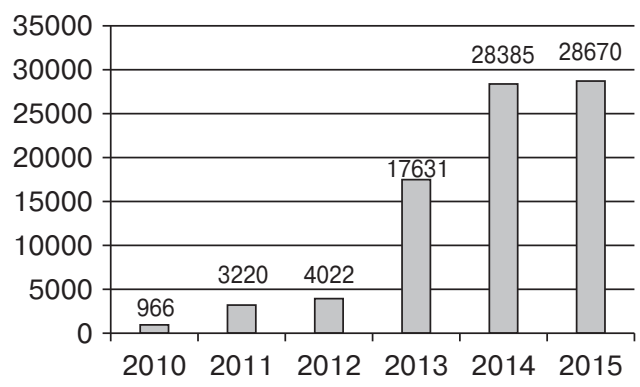

Accepted and pending requests (accumulated stock)

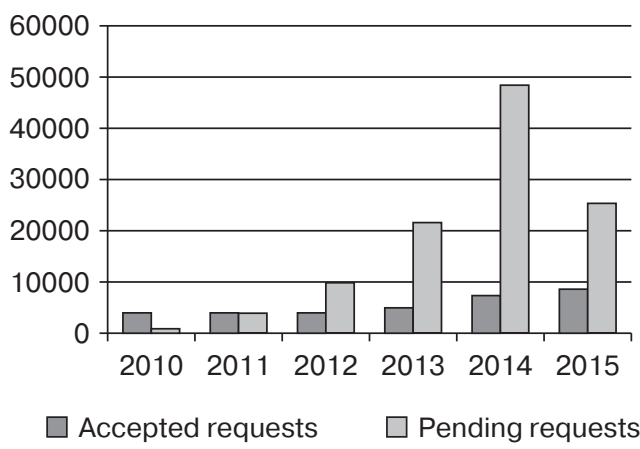

Figure. Asylum-seekers in Brazil (2010-2015) - accepted and pending requests Source: Conare (2016)

\section{Conclusion}

The trends analysed in this article about the current Brazilian immigration context are not separated from the migration dynamics on the global scale, particularly in Latin America. The labour market and the restrictive policies regarding the international population movements by national States are decisive factors to understand this polarized configuration.

Today the immigrant labour in Brazil is not as significant as it has been in the past or as compared to the rates of central countries and other regions of the Middle East. It has therefore low impacts in Brazilian labour market. Nevertheless, this "low percentage" does not justify the marginalization of this issue. Analysers must be careful to do not fall into the traps of the official statistics, in particular those related to the integration of immigrants/asylum seekers in the labour market which underestimate or leave in the shadow a significant part of this social reality.

In fact, the theoretical framework of the polarized configuration highlights that immigration in Brazil is far from being a marginal issue and involves a variety of nationalities, mainly from peripheral countries. It covers a complexity of occupational categories and working conditions in public and private branch of economic activity. This analytical perspective is also useful to reveal the inflows elected to appear in the official statistics as selected skilled or specialized inflows as well as its limits to comprehend the reality of immigration in Brazil.

The current economic and political crisis in Brazil is already resulting in a decreasing trend of these inflows considering both poles of immigration. Nevertheless, the history of immigration in Brazil shows that the immigrant labour force has been a structural factor of labour market dynamic. 


\section{REFERENCIES}

Antunes R. (Org.) (2014). Riqueza e miséria do trabalho no Brasil II, São Paulo: Boitempo.

Baeninger R. (Org.) (2013). Altas Temático: Observatório das Migrações em São Paulo. Campinas: NEPO/UNICAMP.

Estrangeiros autorizados a trabalhar no Brasil. In: CENTRO DE GESTÃO E ESTUDOS ESTRATÉGICOS, Doutores 2010: Estudos da demografia da base técnico-científica brasileira. Brasília: CGEE, 2010.

Bassanezi M.S.C.B. (1995). Imigrações internacionais no Brasil: um panorama histórico. In: Patarra N. (Org.). Emigração e Imigração Internacionais no Brasil Contemporâneo. São Paulo: FNUP

Basso P. (2011). L'ascesa del razzismo nella crisi globale. In: BASSO, Pietro (Org.). Razzismo di stato: Stati Uniti, Europa, Italia. Milano: FrancoAngeli,

Campani G. (2011). Les femmes immigrées dans une société bloquée: parcours individuels et organisations collectives en Italie. Cahiers du Genre. No. 51. P. 49-67.

Carneiro M.T.C. et. al. (Org.) (2010). História do Trabalho e Histórias da Imigração. São Paulo: Edusp,

Castles S., Miller M.J. (1993). The age of migration: international population movements in the modern world. London/New York: MacMillan Press.

Comitê nacional para os refugiados. Sistema de refúgio brasileiro. Desafios e perspectivas. Ministério da Justiça, 2016.

Dreher S. Neoliberalism and Migration: An Inquiry into the politics of globalization. Hamburg: LIT Verlag, 2007.

Ehrenreich B., Hochschild A.R., Global Woman. Nannies, Maids and Sex Workers in the New Economy. New York: Metropolitan Books, 2003.

Lutz H. The 'intimate others': Migrant Domestic Workers in Europe. In: Berggren E.; Likic-brboric B.; Toksoz G.; Trimikliniotis N. Irregular Migration, Informal Labour and Community: A Challenge for Europe. Maastricht: Sharker, 2007.

Mackay S. The commanalities of experience: refugees and recent migrants. In: Mackay S. (Org.) Refugees, Recent Migrants and Employment: Challenging Barriers and Exploring Pathways. New York\&London: Routeledge, 2008.

Mamed L. Trabalho e migração: o recrutamento de haitianos na Amazônia pela agroindústria da carne do centro-sul brasileiro. IX Seminário do Trabalho, Marília, 2014.

Martin P., Manolo A., Kuptdch C. Managing Labour Migration in the Twenty-first Century, New Haven: Yale University, 2006.

Ministério do trabalho e emprego. Base estatística geral das autorizações de trabalho concedidas a estrangeiros, atualizada até 2015.

Morokvasic M. L' (in)visibilité continue. Cahiers du Genre, n. 51, Paris, 2011, p. 25-47.

Perocco F. Le discriminazioni razziali nel lavoro: un fenomeno sistematico e multidimensionale. In: Ferrero M.; Perocco F. (Orgs.). Razzismo al lavoro: il sistema della discriminazione sul lavoro, la cornice giuridica e gli strumenti di tutela. Milano: Franco Angeli, 2011.

Pizarro J.M. Globalizados, pero restringidos: una visión latino-americana del mercado mundial de recursos humanos calificados. CELADE: Santiago, 2005.

Potts L. The World Labour Market: a history of migration. London: Zed Books, 1990.

Preston V., D'Addario S. Recent Migrants in the Canadian Labour Market: Exploring the Impacts of Gender and Racialisation. In: Mackay S. (Org.) Refugees, Recent Migrants and Employment: Challenging Barriers and Exploring Pathways. New York\&London: Routeledge, 2008.

Roulleau-Berger L. Migrer au féminin. Paris: PUF, 2010. 
Sassen S. Brutality and Complexity in the Global Economy. Cambridge, Massachusetts: Harvard, 2014.

Dos enclaves en las geografías globales contemporáneas del trabajo. In: Aragonés A.M. (Org.). Mercados de Trabajo y migración internacional. México, D.F.: UNAM, Instituto de Investigaciones Económicas, 2011.

Sayad A. La double absence: des ilusions de l'émigré aux souffrances de l'immigré. Paris: Seul, 1999.

Schierup C.-U. 'Bloody Subcontracting' in the Network Society: Migration and Post-Fordist Restructuring across European Union. In: Berggren E.; Likic-brboric B.; Toksoz G.; Trimikliniotis N. Irregular Migration, Informal Labour and Community: A Challenge for Europe. Maastricht: Sharker, 2007.

Silva C.F. Trabalho informal e redes de subcontratação: dinâmicas urbanas da indústria de confecções em São Paulo, Dissertação (Mestrado), Universidade de São Paulo, São Paulo, 2008.

Villen P. O estigma da ameaça ao emprego pelos 'periféricos na periferia': crise e imigração no Brasil, Rua. 2015. V. II. P. 247-264.

Imigração na modernização dependente: "braços civilizatórios e a atual configuração polarizada". Tese de Doutorado - Universidade Estadual de Campinas, 2015.

A nova configuração da imigração no Brasil sob a ótica do trabalho. In: Antunes R. (Org.). Riqueza e miséria do trabalho no Brasil III, São Paulo: Boitempo, 2014.

Zanin V. Iforzati del mare. Roma: Carocci, 2007.

Many countries have used this Asian forced labour system during this period, despite of the restrictive policies - based on racist arguments - forbidding it. Brazil is an example.

The analyse of this polarized configuration in Brazil is not based on the immigrant skill - considered individually - but on the legal or undocumented way of entry in the country and its relation with the immigrant insertion in the Brazilian labour market. It do not suggest a dichotomy model, but an analytical perspective that allows to investigate the different inflows and in its relation to labour market. See (Villen, 2014).

See also Baeninger (2010).

The Pré-Sal reserves are huge oil reserves discovered on the submerged lands of the Brazilian Atlantic coast.

Through the Mais Médicos Program, the Brazilian government recruits physicians from other countries to reduce the shortage of this service in the public sector - mainly in some regions of the country. This policy was implemented in 2013. For details, see Villen (2015).

(C) P. Villen, 2017

\section{Article history:}

Received: 28 May 2017

Revised: 05 June 2017

Accepted: 23 June 2017

\section{For citation:}

Villen P. (2017) Immigrant labour in Brazil (2007-2015): the legal and the undocumented circuits. RUDN Journal of Economics, 25 (2), 263-274. DOI: 10.22363/2313-2329-2017-25-2-263-274

\section{Bio Note:}

Patricia Villen, Professor, Social Science Institute of Federal University of Uberl ndia (Ufu Brazil) and researcher, University of Campinas (Unicamp - Brazil). Contact information: e-mail: villenpatricia@gmail.com 


\title{
ТРУД ИММИГРАНТОВ В БРАЗИЛИИ (2007-2015): ЗАКОННЫЕ И НЕЗАКОННЫЕ СХЕМЫ
}

\author{
П. Виллен \\ Университет Кампинаса \\ Барао Джеральдо, Кампинас - СП, Бразилия, 13083-970
}

Статья анализирует трудовую иммиграцию в Бразилию в историческом и современном аспекте. Установлены исторические особенности иммиграционных процессов, а также представлена эволюция государственной иммиграционной политики в Бразилии. Установлено, что на формирование рынка труда Бразилии большое значение оказала эпоха рабовладения. Ввоз рабов из Африки продолжался и после объявления независимости в 1822 году. Переход от рабского труда к наемному произошел во второй половине двадцатого столетия. В дальнейшем, иммиграционная политика Бразилии основывалась на системе квот, в целях защиты внутреннего рынка труда и снижения безработицы среди местного населения. На современном этапе, политика защиты внутреннего рынка труда Бразилии по-прежнему проводится на основе селективного подхода. В качестве основного механизма регулирования выступают рабочие визы. Выявлено, что по мере развития процессов глобализации, Бразилия сталкивается с новыми проблемами, среди которых массовые потоки недокументированных иммигрантов из менее развитых стран Латинской Америки. Выявлено влияние мирового экономического кризиса на миграционные процессы в Бразилии.

Ключевые слова: труд иммигрантов, Бразилия, незаконные схемы

\section{История статьи:}

Дата поступления в редакцию: 28 мая 2017

Дата принятия к печати: 23 июня 2017

\section{Для цитирования:}

Виллен П. Труд иммигрантов в Бразилии (2007-2015): законные и незаконные схемы // Вестник Российского университета дружбы народов. Серия: Экономика. 2017. Т. 25 . № 2. C. 263-274. DOI: 10.22363/2313-2329-2017-25-2-263-274

\section{Сведения об авторе:}

П. Виллен, профессор, Институт социальных наук Федерального университета Уберландии; исследователь, Университет Кампинас. Контактная информация: e-mail: villenpatricia@ gmail.com 